\title{
Walter Murch: a revolução da trilha sonora cinematográfica
}




\section{Resumo}

Este artigo tem por objetivo pesquisar o uso do ruído nas trilhas sonoras realizadas por Walter Murch na década de 70, em especial seu trabalho em $O$ Poderoso Chefão (1972) e em Apocalipse (1979), filmes dirigidos por Francis Ford Coppola. É também objetivo deste estudo demonstrar, através da análise dos filmes acima citados, a importância de Murch na mudança do pensamento sonoro dos filmes norte-americanos de ficção.

\section{Palavras-chave}

cinema, Walter Murch, som, trilha sonora, sound design, edição de som, ruído

\section{Abstract}

The study of sound effect tracks developed by Walter Murch during the 70's is the subject of this article, with special attention to his work in The Godfather and Apocalypse Now. It is also my aim to demonstrate, through these films analyzes, Murch's role in the transformation of the north-american fiction films sound design.

Key words

cinema, Walter Murch, sound, sound track, sound design, sound editing, sound effect 


\section{Introdução histórica}

partir de 1927 , com a implementação comercial de
um sistema que permitia a perfeita sincronização
entre a trilha sonora (trilha de vozes, de música, de ruídos ambiente e de ruídos de efeito) e a imagem de um filme, tanto na captação quanto na exibição, o cinema ganhou um novo leque de possibilidades narrativas. A partir do Vitaphone, não foi mais preciso restringir o som de uma obra cinematográfica aos músicos e/ou objetos que coubessem nò espaço da sala de exibição. A amplificação elétrica do som, pela primeira vez apresentada em salas de cinema, levava a uma nova dimensão da escuta. Podia-se ouvir com intensidade proporcional à grande imagem projetada.

A discussão que a nova tecnologia causaria na linguagem cinematográfica se intensificou a partir desse período. Escrevia-se desde o uso contrapontual do som (Eisenstein, 2002) até a distribuição espacial dos auto-falantes dentro da sala e sua relação com a movimentação dos personagens na tela. Entre o fim dos anos $1920 \mathrm{e}$ início dos 1930, houve um longo debate sobre melhor ou pior audibilidade em proporção ao tamanho dos personagens dentro do quadro. Alguns defendiam que o som deveria acompanhar fielmente o que era visto, ou seja, quanto mais aberto o plano, menor a compreensibilidade das palavras ditas ou de qualquer outra fonte sonora exibida. A decupagem teria que prever o nível de inteligibilidade que seria recebido pelo espectador. Em sua defesa, argumentavam que dessa forma a voz não seria sempre o elemento principal da

1. Por ruídos, usarei a definição de Moraña citada por Giraldo-Salinas, 1989 . "Por ruídos, entendemos todo o som que não seja claramente musical nem lingüístico". 
trilha sonora e se evitaria uma "teatralização" da obra cinematográfica. Já outros profissionais, em grande parte roteiristas, sustentavam que se alguma palavra era dita, ela teria que ser ouvida claramente, não importando se a personagem estivesse em close ou em plano geral $^{2}$.

Porém, a controvérsia teve seu fim decretado pela limitação técnica que o Vitaphone e o seu sucessor, o som ótico, apresentavam. Tanto a extensão dinâmica quanto a resposta de frequiências eram bastante limitadas, restringindo a mixagem a dois, excepcionalmente três sons simultâneos para que não se perdesse compreensibilidade. Se houvesse necessidade de simultaneidade, um dos sons deveria estar bem mais forte que os outros.

O elemento sonoro que teve a primazia nos filmes sonoros emergentes não foi a música (já presente no cinema silencioso), nem os ruídos, mas a palavra que é o elemento mais codificado de todos. Também não existia a possibilidade de se projetar trilhas sonoras com qualquer complexidade sensorial. $O$ objetivo era dar aos espectadores algo claro e compreensivel. Ruídos è música, por sua vez, tiveram que ser o mais estereotipado possivel para serem reconhecidos imediatamente. (Chion, 1994, p.148)

No cinema de animação e em parte dos filmes de ficção, a trilha musical se encarregava de representar as eventuais imagens que pedissem ruídos como trens, passos ou portas. A música também cumpria a função de criar a sonoridade do ambiente. Se, excepcionalmente, houvesse necessidade da utilização de algum ruído de efeito, a partitura era escrita para que no momento da execução do ruído acontecesse uma pausa musical, evitando assim elementos sobrepostos.

Além da limitação tecnológica, havia também uma razão cultural para o pouco uso de ruídos: "o ruído é um elemento do mundo sensorial que é totalmente desvalorizado em nível estético. Até pessoas cultas hoje respondem com resistência e sarcasmo à noção de que

2. Para mais informações, veja ALTMAN, 1992. 
música pode ser feita a partir dele." (Chion, 1994). No período inicial do cinema sonoro, alguns cineastas como Renoir e Vertov optaram pelo uso de ruídos como elementos de narrativa com igual valor da voz ou da música. Algumas décadas depois, Jacques Tati repensaria o uso de ruídos na renovação que fez da pantomima em seus filmes.

Porém, apenas no fim dos anos 1960 e início da década de 1970, com uma melhoria significativa na tecnologia de gravação e reprodução, tornou-se possível uma representação mais complexa e fidedigna dos sons. Com a criação do sistema Dolby, os ruídos não precisavam mais ser estereotipados, assim como vários sons poderiam ser ouvidos ao mesmo tempo sem necessidade de brutais diferenças de intensidade entre eles.

Nesse período também houve uma retomada da trilha sonora como objeto de estudo. Com o estabelecimento do padrão de onipresença da voz acompanhada de uma trilha musical, no meio dos anos 1930, houve uma grande redução dos debates do uso do som. A análise do discurso cinematográfico ficou praticamente restrita à imagem. A maioria dos críticos e teóricos trabalhou com o princípio do cinema ser uma arte essencialmente visual, sendo o som um mero acompanhamento. $\mathrm{O}$ estudo do som cinematogrăfico ficou praticamente restrito ao estudo da trilha musical e, eventualmente, da voz. Houve, então, uma grande defasagem entre a evolução tecnológica e a linguagem de análise da trilha sonora como um todo.

Apenas a partir dos anos 70, esse quadro se modificaria. Pesquisadores como Altman, Bordwell, Weis, Percheron, Tellez e Chion retomaram a discussão esquecida, propondo novas formas de análise que integrassem os elementos visuais e sonoros na discussão da obra cinematográfica. Mesmo assim, o foco continuou (como ainda continua) sobre o uso da música e da voz, deixando a trilha de ruídos em segundo ou terceiro plano, quando lembrada.

\section{O uso do ruído}

Mesmo depois da evoluç̧ão tecnológica do som, opreconceito cultural contra o ruído continuava. Os elementos formadores da trilha sonora cinematográfiẹa tradicionalmẹte seguiam funções específicas 
e obedeciam a uma ordem hierárquica. A voz tinha a função maior de informar o tema, o desenvolvimento da história e a caracterização dos personagens. A música refletia situações de caráter emocional dos personagens ou da história. Já os ruídos de sala e efeito eram responsáveis pela manutenção do caráter verossimilhante da imagem enquanto os sons ambientes serviam para indicar quando e onde os fatos ocorriam. (Zettl, 1973).

Quanto à audibilidade, continuava a hierarquia onde a trilha de vozes era a mais intensa e a trilha de música, a segunda mais audível. Nos trechos sem falas, a trilha de música crescia para o mesmo nível de intensidade usado na pista de vozes. Em seguida, eram ouvidas as trilhas de ruídos onde internamente também havia uma hierarquia de intensidade: os ruídos de efeitos, ruídos de sala e ruídos ambientais, do mais ao menos intenso.

Walter Murch rompeu, em seus trabalhos dos anos 70, com essa tradição, fazendo com que qualquer estímulo sonoro pudesse servir para acentuar tanto o caráter verossimilhante como o caráter emocional da obra, seja ele música, ruído ou voz.

\section{Walter Murch}

Walter Murch faz parte da geração dos primeiros estudantes de cinema a chegarem aos grandes estúdios norte-americanos. Nascido em 1943, Murch cresce em Paris onde tem o primeiro contato com a música concreta. Mas é na adolescência, quando se muda para Nova Iorque, que começa a ouvir intensivamente autores que propõem novas experiências musicais como Pierre Henry e Pierre Schaeffer.

Nos anos 60, Murch resolve unir suas duas paixões: a música concreta e os filmes. Não que ele se considerasse um compositor, mas as obras concretistas o ensinaram a tratar os sons naturais em um contexto fora do usual. Para tanto, ingressa no curso de cinema da University of Southern California onde conhece George Lucas, Francis Ford Coppola, John Milius e Caroll Ballard. Na USC, a maioria dos seus colegas achava que o som não era parte essencial dos filmes - "It was just sound" (LoBrutto, 1994, p.84). Diante desse quadro, 
Murch acabou sendo o estudante procurado cada vez que seus colegas precisavam de uma trilha sonora diferenciada. No final do curso, Lucas disse a ele que Coppola estava montando um estúdio em São Francisco e não tinha ninguém para cuidar da parte de som. Murch aceitou o convite e entrou no projeto do Zoetrope Studios onde iria revolucionar tanto o pensamento, quanto a forma de produção da trilha sonora cinematográfica.

Em seu primeiro trabalho na Zoetrope Studios, Caminhos Mal Traçados (1969), Murch já começa a rascunhar o uso dramático da trilha de ambientes e ruídos. Na primeira cena do filme, os ruídos de lixeiros trabalhando aparece de forma verossimilhante para logo em seguida funcionar como elemento que espelha a tensão de Natalie Ravenna, o personagem principal. Na cena seguinte, a forte intensidade do som do chuveiro na trilha sonora misturado às vozes dos lixeiros já mostra a procura de Murch por um som ambiente que não apenas redunde o espaço da imagem, mas que acrescente informações sobre o estado emocional dos personagens. Essa busca poderá ser vista (e ouvida) ainda em outras seqüências, como nas cabines telefônicas, onde os caminhões passando em "off" servem para intensificar o desespero da esposa fugitiva, ou mesmo em todas as sequiências de motel onde o ruído fortíssimo das auto-estradas manterá presente a intranqüilidade do personagem em cena.

A opção pela intensidade exagerada do som da estrada é claramente uma opção estética e não uma consequiência da captação de som direto já que na única sequiência em que Natalie consegue relaxar, o ruído desaparece no meio da cena, deixando apenas as vozes dos personagens na trilha sonora. É também nesse filme que Murch começa a utilizar alguns sons eletrônicos mixados a sons naturais para conseguir criar novos timbres nos ambientes sonoros.

Mesmo que o projeto de som de Caminhos Mal Traçados apresente uma renovação na maneira de pensar os ruídos, sua realização é precária. Todos os sons que compõem as trilhas de ambiente e ruídos são ouvidos com pouquíssima diferença dinâmicas entre eles, o que retira definição na sua leitura.

Apenas em seu trabalho seguinte, $T H X 1138$ (1970), Murch descobre que, para que todos os sons possam ser claramente ouvidos, 
é necessário criar uma perspectiva sonora. Para conseguir o impacto do caos sonoro na sequiência onde THX é envolvido por uma multidão, Murch gravou vários ruídos de grande movimento: trânsito em túneis, uma eufórica platéia num jogo e várias cachoeiras. Porém, ao juntar todos esses elementos, ele não conseguiu obter a sensação sonora de forte intensidade desejada, mesmo que eletronicamente estivesse no limite físico da saturação. A solução viria ao acrescentar à mixagem anterior uma voz saída de um sistema de alto-falantes: "Isso tem a ver com psicoacústica. Se a mente tem um som pontual para focar, ela nos faz ter uma relação diferente com os outros sons. Quando você tem apenas sons fora de foco, é difícil ter uma noção deles.'(LoBrutto, 1994, p.86).

A trilha de ambientes de THX 1138 também dá continuidade ao caminho iniciado no filme anterior. Seguindo a idéia de George Lucas de um "futuro velho", Murch criou um universo sonoro ambiental produzido basicamente por sons acústicos/mecânicos, evitando o uso de sons eletrônicos, típicos de filmes de ficção científica. A dureza e repetição dos ruídos ambientais são usados para enfatizar o caráter massificante da sociedade futurista apresentada. E acaba por cumprir uma função normalmente reservada à música - refletir situações de caráter emocional da narrativa. A música propriamente dita é usada apenas em situações de romance entre o casal principal.

Em THX 1138, Murch também criou uma nova forma de produção (e pensamento) da trilha sonora cinematográfica através da figura do montador de som, um profissional que supervisiona todas as etapas de realização do som cinematográfico: captação, edição e mixagem. Até esse momento, ao contrário da maioria das áreas técnicas de realização cinematográfica, não havia um único profissional responsável pela sonoridade da obra. O técnico de som direto era o responsável pela captação durante o período de filmagem; o editor de som, pela edição da trilha de som direto e pela escolha e sincronização de ruídos, quase sempre selecionados da coleção de ruídos pertencente ao estúdio produtor. E havia também o criador de ruídos de sala; o técnico de gravação de ruídos de sala; o editor de música e o mixador, o responsável pela inter-relação final de intensidade entre todos esses sons. O montador de som passou a ser, 
a partir de $T H X 1138$, o responsável pela unidade sonora do filme. Alguém que acompanha da discussão do roteiro na pré-produção à exibição da primeira cópia.

Em seu trabalho seguinte, O Poderoso Chefão, Murch rompeu definitivamente com o padrão de construção de trilha sonora, quer em audibilidade ou no uso dramático. Não há distinção nas funções narrativas da música, dos ruídos ou das vozes. Como dito anteriormente, qualquer estímulo sonoro pode servir para acentuar o caráter verossimilhante, assim como o caráter emocional. Isso também se reflete no volume de escuta dos sons: a hegemonia da trilha de vozes e da trilha de músicas não mais existe. $\mathrm{O}$ som mais audível será aquele que acrescenta informações à imagem. Os ruídos passam a ser, então, elementos complementares à imagem, e não apenas elementọs de redundância. Outra mudança proposta por Murch foi o fim do uso de ruídos vindos de arquivos dos próprios estúdios produtores. A partir de $O$ Poderoso Chefão, novos ruídos eram gravados para cada filme, dando-lhes, assim, uma identidade sonora única.

Em Loucuras de Verão (1973), Murch parte para outra experiência. O roteiro de George Lucas exigia a audição contínua de um programa de rádio durante todo o filme. No processo de montagem do filme, Murch e Lucas criaram inicialmente toda a programação de uma emissora, com locuções, músicas e comerciais e é sobre essa trilha que a imagem do filme foi montada. Uma vez terminada essa etapa, para evitar que a sonoridade do rádio e das vozes das personagens competissem em compreensibilidade, Murch regravou os trechos dos programas de rádio nos espaços onde se passa a ação. Se no início do filme esse programa está sendo ouvido por um rádio de cạrro, o som que está no filme foi gravado dentro de um veículo. O mesmo vale para todos os outros espaços onde ele é ouvido, como a lanchonete, o ginásio de esportes e a própria estação de rádio. Com essa solução acústica, o som do rádio que já dialogava como uma voz contrapontística, ganhou ainda maior integração ao espaço da imagem.

A Conversação (1974) talvèz tenha a relação audiovisual mais complexa das obras realizada por Murch. É um filme onde os 
trechos de imagem e som da conversa gravada na praça são apresentados em diversas combinações. O mesmo segmento de diálogo é associado a diferentes imagens assim como uma mesma imagem é associada a variados momentos de diálogo. E é por essas associações que o espectador vai aprendendo, junto com o detetive, qual o verdadeiro sentido daquela conversação. Talvez a complexidade da narrativa audiovisual desse filme aconteça por Murch ser resp̉onsável pela edição de imagem, além da montagem de som. Isso faz com que todas as imagens e todos os sons sejam pensados de forma interdependente. Já nos outros trabalhos, mesmo que possa ter interferido na edição de imagem, ele não teve controle absoluto sobre seu resultado. A criação das trilhas sonoras foi feita depois da montagem de imagem estar pronta e não concomitantemente a ela, o que exige um outro tipo de pensar.

Seu trabalho posterior, O Poderoso Chefão II (1974), não traz nenhuma inovação em relação ao que já havia feito. Talvez até por ser uma edição realizada em um prazo muito curto, já que Murch dedicou parte do tempo que seria aplicado nesse filme à finalização de A Conversação.

Murch chega a seu auge do uso criativo da trilha sonora cinematográfica em Apocalipse (1979). Desta vez, a trilha de ruídos ambientais assume um caráter absolutamente não-verossimilhante. Os sons ambientais passam para a primeira pessoa da narrativa, fazendo audíveis os estados emocionais do personagem principal. Esta prática é usada de diversas formas, como recriando a audição seletiva das personagens, como externando sons presentes no subconsciente dessas personagens, o que gera uma maior aproximação entre espectador e filme. É também em Apocalipse que Murch criou a denominação de sound designer, ou projetista de som. Esse profissional passa a ser o responsável não só pela unidade de produção da trilha sonora, mas, também, por toda a sonoridade de uma obra.

Depois de Apocalipse, Murch pára de editar som e passa a se dedicar apenas à edição de imagem e à mixagem. A única exceção foi em O Paciente Inglês (1996), onde ele reproduziu o processo de trabalho de $A$ Conversação. 
Para este artigo, escolhi fazer uma análise de $O$ Poderoso Chefão por considerá-lo um paradigma da renovação do pensamento sonoro cinematográfico proposta por Murch. Mesmo que a idéia do uso dramático da trilha de ambientes e ruídos já apareça em seus dois primeiros filmes (Caminhos Mal Traçados e THX 1138), é em $O$ Poderoso Chefão que Murch cristaliza de forma organizada esse uso. A divisão em seqüências que utilizei em $O$ Poderoso Chefão e em Apocalipse segue um padrão sonoro e não espacial ou visual. Essa opção faz com que duas ou mais seqüências sejam unidas em um mesmo bloco, quando não há nenhum uso diferenciado da trilha sonora que necessite destaque. A seguir, analiso aquelas que desenvolvem o uso criativo da trilha sonora e sua relação com a imagem.

\section{Análise da trilha sonora de O Poderoso Chefão}

Na primeira seqüência (Diálogo de Bonasera com $D$. Corleone) é apresentado o escritório de D. Vito Corleone. O som ambiente criado para esse espaço é "completamente silencioso". Mesmo que esteja acontecendo uma grande festa de casamento no jardim da residência e que a janela do escritório dê para esse jardim, nenhum som externo irá intervir nas conversas que aí acontecem durante todo o desenrolar do filme. $O$ escritório será, então, como um templo onde o mundo externo não pode interferir, um espaço onde o domínio de $\mathrm{D}$. Corleone é absoluto. $\mathrm{Na}$ sequiềncia 01 , a ausência de sons ambientes também tem a função de valorizar o discurso de Bonasera, emblemático no filme. As duas únicas exceções acontecerão no final desta sequiência e na seqüência $10(D$. Corleone com Luca Brasi). No primeiro caso, a abertura de porta para a saída de Bonasera nos deixa ouvir o som de alguns instrumentos sendo afinados, o que continua mesmo depois do fechamento da porta. Desta forma, Murch facilita a passagem para a seqüência seguinte, evitando o estranhamento que aconteceria com o corte direto da ausência de som do escritório para uma grande orquestra tocando na festa de casamento. $\mathrm{O}$ afinar dos instrumentos também cria uma "desculpa" 
do porquê não se ouviria nem música nem vozerio de pessoas dentro do escritório: a festa não teria começado, pois a orquestra acabara de chegar.

Criar justificativas, como no exemplo anterior, para que uma proposta diferenciada do uso da trilha sonora não gere um estranhamento no espectador, é uma prática que Murch manteria ao longo dos anos 1970: Somente a partir de Apocalipse que ele faria um uso poético da trilha sonora sem necessidade de demonstrar uma fonte diegética do som.

Nas sequiências que compõem o início do filme (seq: 01 a 29/escritório-festa de casamento), a trilha musical é a responsável pelo ritmo interno das sequiências, assim como pela articulação entre elas. É pela informação musical que nos são apresentadas características da família Corleone: o contraste entre o erudito e o popular e entre a cultura italiana dos imigrantes e a norte-americana de seus descendentes. $\mathrm{O}$ uso da trilha musical também reforçará a diferença entre as duas cerimônias de casamento na obra. $\mathrm{Na}$ seqüência 76. (Casamento de Michael e Apolonia), também há a estrutura de música diegética marcando a festa que se encerra com uma valsa. Só que, desta vez, não é uma grande orquestra e vários cantores que são ouvidos e sim, uma pequena banda local.

A sequiência 35 (Woltz descobre a cabeça do cavalo) é um dos exemplos da forma que Murch se utiliza de voz, mûsica e ruído com a mesma força dramática. Essa seqüência abre com a externa da casa de Woltz em plano geral. Na trilha sonora, ouvem-se grilos. À medida que a câmera se aproxima da janela do quarto, inicia o tema principal do filme tocado por um trompete, trazendo ao espectador a presença de $\mathrm{D}$. Corleone naquele espaço. No corte para dentro do quarto, a música ocupa o primeiro plano de som e acompanha os movimentos de Woltz ao abrir o lençol. Na trilhă sonora também há os ruídos do lençol e pequenas interjeições de Woltz. Essa é uma estrutura audiovisual convencional: a música redunda os movimentos da imagem enquanto os ruídos de sala, assim como as reações de Woltz, dão presença ao personagem.

Um grande achado de Murch nesta sequiência está no deslocamento do ápice da cena. Ao invés de fazer com que a música 
chegue ao clímax na revelação da cabeça do cavalo, Murch opta pelo silêncio para, em seguida, fazer com que Woltz grite. Os gritos, introduzidos depois da respiração na música, são o único elemento presente na trilha sonora. A falta de som ambiente assim como a opção de captação da voz - com o microfone bem afastado da fonte, gerando muito ar em volta - faz com que o grito de Woltz fique mais desesperado. É um grito solitário, perdido no espaço onde ninguém pode ouvir. No fim da seqüência, a câmera descreve um movimento contrário ao inicial - sai pela janela do quarto até chegar no plano geral da casa. Na trilha sonora, o ambiente de grilos é retomado na externa. A intensidade do som ambiente faz o movimento contrário à imagem: à medida que os planos ficam mais abertos os grilos ficam mais fortes até encobrirem completamente os gritos de Woltz.

$\mathrm{Na}$ seqüência seguinte, 36 (D. Corleone conversa sobre Sollozzo/Chegada de Sollozzo), há uma montagem paralela entre a conversa de D. Corleone com os filhos e a chegada de Sollozzo no segundo escritório dos Corleone. A conversa segue em "voz over" nos planos de Sollozzo. Murch opta, então, por uma estrutura que irá repetir em outros trabalhos que também apresentam "voz over": a sonorização da imagem que está sendo vista. Dessa forma, ele mantém a ligação entre espectador e imagem - basicamente por ruídos de sala - evitando um afastamento que imagens e sons com fontes completamente diferentes poderiam causar, além de reforçar a apresentação do personagem Sollozzo, não apenas pela fala de Hagen, mas, também, pelo reforço sonoro das imagens.

Na seqüência 37 (D. Corleone com Sollozzo), durante a conversa entre Sollozzo e os Corleone, pode-se ouvir ruídos ambiente, tanto externos (carros, vozes) quanto internos (máquinas de escrever, portas, etc.) que acentuam a diferença entre os dois escritórios de D. Corleone. Este segundo escritório, que fica na cidade, não possui o mesmo caráter daquele que fica em sua casa. Este local pertence a um tempo e um espaço definidos.

A sequiência 39 (Michael e Kay fazem compras) abre com um "fade" a partir do preto. Desde a ponta preta já se ouve a canção "Have Yourself A Merry Little Christmas". Mais uma vez, a trilha musical introduz rapidamente o tempo da ação, desta vez, o Natal. 
Michael e Kay andam pela rua conversando sobre presentes. $\mathrm{O}$ diálogo é leve, assim como a canção. No corte para a seqüência seguinte, a canção passa a ser diegética, vinda de um rádio de cena. É interessante observar como Murch usa a música para dar continuidade temporal entre as duas seqüências e, ao mesmo tempo, transforma o caráter da trilha musical. Se antes ela ajudava na criação de uma cena suave e delicada, agora ela traz "aspereza". Se antes a voz do cantor era macia, agora ela é deformada pela transmissão do rádio. Essa diferença gerada pela trilha musical aumenta o contraste criado pela imagem, que troca um alegre casal fazendo compras natalinas por um mafioso se armando antes de sair de casa.

Aliás, grande parte da qualidade do trabalho de Murch devem-se às escolhas timbrísticas de seus sons. Através dessas escolhas, Murch é capaz de indicar clara e rapidamente o estado emocional dos personagens em cena. A grande reverberação dos espaços que cercam Harry Caul em $A$ Conversação amplia sua solidão. A voz amplificada e distorcida dos confessionários em $T H X$ 1138 contrasta com a humanidade das vozes naturais dos trabalhadores. $\mathrm{O}$ timbre grave, pausado e etéreo da locução de Willard em Apocalipse faz com que o personagem fique próximo a uma divindade. As diferentes hélices de helicópteros em Apocalipse, os diferentes tiros em $O$ Poderoso Chefão, as diferentes equalizações da conversa em A Conversação, todos esses são exemplos que trazem em comum texturas que deixam a verossimilhança para dar ao espectador uma experiência emocional, para que ele receba e sinta novas informações de forma não-racional, quase sub-liminar, como somente é possível através universo sonoro.

O próximo uso diferenciado da trilha sonora que Murch irá fazer está na sequiência 42 (Morte de Luca Brasi). Assim como na seqüência 44 (Tentativa de assassinato de $D$. Corleone) e na maior parte das sequiências de assassinato de $O$ Poderoso Chefão, não há acompanhamento musical, ao contrário do padrão norte-americano onde esse tipo de cena é normalmente associado a agitação, a correrias e sempre acompanhado de músicas que acelerem o tempo de leitura da imagem. Em ambas as cenas, tudo que ouvimos são os gemidos das vítimas e os ruídos de sala das cenas. Desta forma, as 
cenas perdem a velocidade rápida normalmente a elas vinculadas e passam a fazer parte do cotidiano das pessoas envolvidas no filme.

A opção de Murch pelo uso apenas de ruídos e vozes nas sequiências de assassinato vai de encontro à opção de Coppola por não contar uma história de gangsteres e sim a história de uma família de imigrantes italianos que tem a Máfia como profissão. Afinal, o uso de trilha musical não diegética sempre carrega consigo um caráter de interferência e manipulação da informação. É só lembrarmos de uma das regras clássicas do uso da trilha sonora em filmes documentais - a proibição do uso de músicas sob entrevistas.

A sequiência 42 começa com Luca Brasi andando por um corredor indo ao encontro de Sollozzo. A grande reverberação nos passos de Brasi e um assobio distante e solitário reforçam a criação do espaço solitário. Com a entrada de Brasi no bar, o som ambiente silencia-se por completo. A partir desse momento, o ritmo das vozes, o intervalo entre elas e sua integração com os ruídos são responsáveis por gerar o tempo interno da cena. Não há nenhuma música que introduza a morte por acontecer. $\mathrm{O}$ assassinato é rápido: Sollozzo, auxiliado por um garçom, prende a mão de Brasi no balcão com uma faca enquanto outro mafioso o asfixia com uma corda. Enquanto isso, ouvimos apenas o que resta de ar em Brasi sair pela sua garganta e seu corpo batendo no balcão do bar.

A sequiência encerra com a câmera observando Brasi caindo no chão através do vidro externo do bar. Murch então abre uma concessão na opção verossimilhante e faz com que Brasi seja ouvido à distância com a mesma intensidade que o era dentro do bar. Dessa forma, ele mantém a ligação emotiva do espectador com a personagem até o fim da seqüência.

O som ambiente do início da seqüência 44 (Tentativa de assassinato de $D$. Corleone) é rico em informações. Há carros ao longe, indicando a proximidade de uma grande avenida, muitas vozes, passos e um trompetista ensaiando ao longe, sons que nos levam a crer que esse lugar é densamente habitado. Todos esses sons diminuem em intensidade quando começamos a ouvir os passos dos assassinos de D. Corleone e, principalmente, os tiros. Agora, Murch constrói o espaço de uma outra forma: usando uma leve reverberação 
no som dos tiros. Na fuga dos assassinos, o som ambiente é retomado por um cachorro que late e um bebê que chora, acentuando a confusão gerada. Quando D. Corleone cai, inicia o tema principal do filme de forma suave contrastando com o desespero dos gritos de Fredo. O choro do filho, a trilha musical e som de buzinas de carros ao longe, que substituem o cachorro e o bebê no som ambiente, encerram a seqüência.

Aqui, a trilha de ruídos que leva ao espectador o caráter emocional da história. Se no início ela coloca D. Corleone em meio ao caos sonoro da cidade, em seguida faz com que o foco seja transferido para a chegada dos matadores e na violência dos tiros contra o Chefão para depois, no fim da seqüência, fazer-nos sentir a cidade esvaziada e triste.

No início da seqüência 55 (Michael chega no hospital), é interessante notar a opção sonora que Murch usa para reforçar a idéia do hospital desabitado: o som de um disco arranhado, repetindo infinitamente o mesmo trecho de música sem que ninguém mude a agulha de lugar.

Logo em seguida, há uma sequiência construída apenas por ruídos (Chegada de Enzo). No início, há um reforço dos sons da cama de D. Corleone sendo arrastada pelos corredores do hospital. Com o som de uma porta que é aberta, os sons da cama ficam menos intensos e toda a tensão da cena é construída pelos passos que reverberam pelo espaço vazio do hospital e se aproximam cada vez mais do local onde estão Michael e a enfermeira. Uma vez terminado o suspense pela revelação de Enzo, o ruído dos passos perde sua importância dramática e deixam o primeiro plano de som. No fim da sequiência, a relação emocional entre Michael e Vito Corleone é intensificada com a volta do tema principal. No plano seguinte - Michael andando pelo corredor do hospital - esse tema é esvaziado para dar lugar ao tema de suspense no início da seqüência 58 (Michael com Enzo na frente do hospitall Chegada dos policiais). Mais uma vez, a manipulação das qualidades do som, neste caso da amplitude, deixa clara a opção de Murch pelo uso dramático do ruído para a construção da tensão narrativa. 
A seqüência 61 (Michael com Clemenza) se passa em um espaço pouco definido - uma garagem, um porão. Seu ambiente sonoro é igualmente indefinido: água pingando e um som como uma caldeira, que criam um espaço com presença, mas com baixo volume. Na seqüência, Clemenza ensina Michael a matar. É criada uma grande tensão para o disparo do revólver. Esse disparo é grandioso. Não é igual aos outros tiros que já aconteceram no filme. Este tiro não é. verossimilhante, há um componente eletrônico na sua criação que acentua a intensidade do som gerando impacto no espectador. Esse impacto é tão forte que a possibilidade de um segundo tiro na cena cria grande expectativa, frustrada no final da seqüência quando descobrimos que a arma está descarregada.

A seqüência 64 (Externa do restaurante) é um dos melhores exemplos para demonstrar o pensamento.sonoro de Walter Murch. Ela começa com a apresentação do espaço externo de um restaurante. Nele podemos ouvir a existência de uma linha de trem bastante próxima. Mesmo que não exista nenhuma referência na imagem dessa linha, o som do trem é bastante intenso. Tão intenso que prossegue na cena seguinte, dentro do restaurante, mesmo com uma clara elipse temporal na imagem. Esse é um som bastante importante para Murch, pois será utilizado no decorrer da seqüência para expressar o sentimento de Michael. E, como é típico de seu trabalho, primeiro o som é utilizado de forma verossimilhante para depois ganhar um caráter expressionista.

Dentro do restaurante há pouca presença de ruídos na trilha de ambientes - apenas um leve burburinho de vozes. Os ruídos de sala (abertura da garrafa de vinho, passos do garçom) ganham destaque. Sollozzo e Michael começam, então, um diálogo em italiano. Durante essa conversa, um trem passa em terceiro plano de som. Quando Michael se levanta para ir ao banheiro, outro trem volta a passar também com pouco mais de intensidade. $\mathrm{O}$ ambiente dentro do banheiro é composto pelo som de água enchendo a caixa d'água da descarga que leva ao ambiente uma sensação de vazio e amplia o desespero de Michael a procura de uma arma escondida. Após Michael puxar a descarga, ouvimos o início do som dentro do banheiro e seu final dentro do restaurante, como se Sollozzo e McCluskey 
também o ouvissem. Antes de voltar para a área de refeição, Michael indica nervosismo passando as mãos na cabeça. Nessa mesma hora, passa um trem com a mesma intensidade da cena externa inicial, claro reforço ao seu estado de espírito. O final desse som faz a ligação entre a cena interior no banheiro e a volta de Michael à mesa de jantar e só termina quando Sollozzo voltar a falar. Michael está absorto em seus pensamentos e não mais ouve Sollozzo.

A tensão interna pela qual ele passa começa a ser externada por um trem que se aproxima. Esse trem traz um novo componente em sua construção sonora: guinchos do atrito do metal das rodas contra os trilhos, um ruído bastante enervante para nossa audição. Quando esse ruído atinge seu ápice, Michael levanta da cadeira e atira contra os dois inimigos. O som do trem é interrompido secamente pelos tiros, afirmando seu caráter não verossimilhante. No fim dos tiros; há uma última respiração do trem, agora sem o componente metálico e bastante distante.

Várias características estilísticas de Walter Murch podem ser vistas e ouvidas nessa seqüência: o ruído diegético que se transforma na expressão dos sentimentos dos personagens, o timbre do som que se modifica ao longo da seqüência e recria sua leitura e a construção verossimilhante do ambiente sonoro que é sutilmente alterado para enfatizar as pequenas nuances narrativas ao invés de se conservar na descrição topográfica e temporal.

Da mesma maneira que Murch cria ambientes e ruídos complexos para sua expressão, algumas vezes a opção apenas pelo uso do som direto é capaz dà mesma riqueza narrativa. Um exemplo disso é a seqüência 79 (Briga de Connie com Carlo). Toda a dramaticidade sonora da cena é construída pelo jogo das vozes do casal Carlo e Connie que se alternam em sonoridade, algumas vezes estando presentes em primeiro plano e outras, se perdendo no espaço da reverberação. A presença marca a atitude de poder de Carlo enquanto a reverberação acentua o desespero de Connie. A voz como o elemento principal da sequiência fica claro no seu final quando os dois personagens saem de quadro ao entrar em um banheiro e toda a ação é construída off-screen com a briga sendo ouvida pela reflexão dos gritos em um espaço pequeno e coberto 
de azulejos. Um grito forte de Connie faz o corte para a sequiência seguinte.

O grito de Connie é imediatamente seguido pelo grito do bebê que está no colo de Mama Corleone enquanto atende o telefone da filha. Os gritos que fazem a ligação entre as sequiências fazem com que a histeria e a agressividade da briga entre Connie e Carlo não seja rompida pela mudança de espaço. Não é dado ao espectador um intervalo de descanso, o que acentua ainda mais a reação colérica de Sonny. $O$ bebê continua chorando até o fim da seqüência, preservando tensão todo o tempo.

$\mathrm{Na}$ sequiência 82 (Morte de Sonny) a opção por não haver trilha musical em assassinatos se mantém. A escolha de Murch, então, para criar um pulso para a cena e gerar tensão no espectador se faz pelo uso de sons de carros. Ao ficar preso entre dois carros ao lado de uma guarita de pedágio, Sonny fica aflito para seguir viagem. Essa aflição é acentuada pela aceleração constante do carro à sua frente assim como pela buzina do carro do próprio Sonny. O tilintar de uma moeda em primeiro plano faz com que o cobrador se abaixe, fechando a janela da guarita simultaneamente. Um rádio que era ouvido até então se cala, e o carro da frente pára de acelerar. Todo o ambiente se torna silencioso e abre espaço na trilha sonora para a saraivada de tiros de metralhadora que ocupam o primeiro plano da trilha sonora. Com a saída de Sonny do carro, seus gritos também são ouvidos. No fim do tiroteio, os carros partem em off. O som de gaivotas volta a fazer parte do ambiente, gerando uma falsa calmaria no fim da seqüência.

$\mathrm{Na}$ seqüência 86 (Michael com Fabrizio/Assassinato de Appolonia), assim como na 102 (Michael com Connie/Michael com Kay/Michael com mafiosos), pode-se observar como o padrão de construção de trilha sonora não segue exatamente a relação espacial dada pela imagem e sim a importância narrativa. No primeirọ caso, a voz de Appolonia não se modifica em intensidade quer em planos próximos ou em planos mais afastados. É necessário manter o espectador vinculado à personagem que irá morrer em seguida. Já na última sequiência do filme, mesmo que Kay esteja em primeiro plano; ouvimos muito claramente a ação de Michael em segundo 
plano. Em ambos os casos, é mais importante para o desenvolvimento da trama ou para a caracterização dos personagens que se ouça o que está sendo dito em segundo ou terceiro plano de imagem do que fazer com que o som siga a mesma perspectiva da informação visual.

É curioso notar na sequiência 90 (Michael, D. Corleone e mafiosos no escritório) a transformação do espaço sonoro do escritório de D. Corleone. Agora, Michael assumiu a liderança da família, e este é o seu escritório. $O$ espaço sacro não mais existe. $O$ ruído externo de crianças brincando também invade o ambiente. Existe até um aquário cuja bomba de ar gera ruído durante todo o tempo.

A sequiência 95 (Morte de D. Corleone) é outra onde a trilha sonora é construída pelo som direto. Sua imagem apresenta um caráter quase documental: todo o início é construído por apenas dois planos onde a câmera permanece afastada. $\mathrm{O}$ uso apenas do som direto reforça essa idéia trazendo à morte do Chefão uma grande naturalidade.

A relação imagem/som da seqüência 97 (Batizado/ Assassinatos) talvez seja a mais expressiva de todo o filme. Para manter a continuidade da sequiência tão fragmentada na imagem e, ao mesmo tempo, reforçar a diversidade das cenas, Murch usa um recurso muito inteligente: a voz do padre prossegue por todo decorrer da sequiência, criando o primeiro traço de união. A música de órgão, apresentada como diegética na igreja, também é ouvida todo o tempo. Mas, sua função não é apenas de continuidade. Ela também funciona como trilha musical que comenta a ação dos comandados de Michael. Dentro da igreja, a música ouvida é composta por notas agudas, brilhantes, enquanto nas cenas de preparação das mortes e dos assassinatos é usada a parte da melodia composta de notas graves, escuras. Assim, Murch consegue manter a continuidade da trilha musical por toda a sequiência, criando diferentes espaços sonoros que comentam a ação específica de cada cena. Mais uma vez, os ruídos de sala também são usados para gerar uma maior integração entre imagem e som.

No início da sequiência, ouvimos oórgão e um bebê chorando. O padre começa o rito do batismo em latim. Sua voz segue em continuidade para o plano seguinte onde Neri prepara sua arma. A 
música se torna grave, modificando seu caráter de sacro para misterioso. Os ruídos de sala também ficam mais presentes na trilha sonora. Na volta ao espaço da igreja, a música retoma seu brilho. No corte para a barbearia, Murch se aproveita do desenho da espuma de barba saindo do frasco para a mudança de tom da trilha musical, sincronizando-o com um acorde de mesma duração e espessura. Desta vez, o órgão grave chega a soar no interior da igreja; mas por pouco tempo. Logo, a leveza é retomada na trilha musical. $O$ padre então começa a fazer as perguntas sobre a crença católica de Michael. Após a primeira pergunta ("Do you believe in Jesus Christ, His only Son our Lord?"), a música pára, como se esperasse por uma resposta de Michael para voltar a agir. A resposta de Michael ("I do.") é a deixa para o começo da ação. A música faz uma série de notas ascendentes como que iniciando uma nova fase da seqüência e retoma o timbre fechado. Agora, além da voz do padre, as respostas de Michael também são ouvidas nos planos fora da igreja, marcando mais ainda sua presença nos eventos que acontecem.

Na volta à igreja, não há uma interrupção da trilha musical. Ela continua sendo construída por notas ascendentes que intensificam cada vez mais a seqüência. $O$ bebê de Connie volta a chorar. Esse choro acompanha o padre e a música nos planos dos empregados de Michael se aproximando de suas vítimas, aumentando a tensão das cenas. $\mathrm{Na}$ retomada da câmera no interior da igreja, a música se cala para deixar ouvir a pergunta do padre ("Michael Francis Ricci, do you renounce Satan?"). Essa fala serve de anacruse para a entrada da música no plano seguinte, um acorde ascendente que acompanha a abertura da porta do elevador. Os tiros de Clemanza encobrem a saída da música. O silêncio acompanha a resposta on-screen de Michael ("I do.") Outra vez, a voz é o anacruse para a volta da música, desta vez sobre as imagens do assassinato de Moe. A estrutura de silêncio sobre Michael e.música sobre as mortes é repetida mais uma vez. Porém, a partir da sua entrada no assassinato de $\mathrm{D}$. Cuneo na porta giratória, não se ouve mais respirações na trilha sonora. Ruídos de sala e tiros acompanham a música em todas as mortes. No fim da sequiência 97 também há o fim da trilha musical. 
Walter Murch em $O$ Poderoso Chefão propõe uma nova forma de pensar o uso da trilha de ruídos e da trilha de ambientes, a qual será posteriormente desenvolvida por ele em Apocalipse. Essas trilhas não são apenas elementos ilustrativos do que já é apresentado pela imagem. Pela trilha de ambientes, aprendemos mais sobre a trama que está sendo desenvolvida ou sobre os personagens que fazem parte dessa trama. Os sons ambientais envolvem o espectador em espaços sonoros que indicam tensão, paixão, poder, conflito. O "controladamente silencioso" escritório de D. Corleone, por exemplo, é invadido por sons externos quando ele perde seu cargo de liderança. Podemos ouvir ainda corvos que anunciam desgraças e um disco arranhado que sublinha o hospital abandonado. A trilha de ruídos não é usada aqui apenas como uma redundância do que já vemos. Eles externam os sentimentos dos personagens, aumentam o impacto ou a expectativa, conduzem a narrativa e funcionam, muitas vezes, como trilha musical.

\section{Análise da trilha sonora de Apocalipse}

O primeiro som de Apocalipse começa sobre uma ponta preta. É o som agudo, com velocidade de rotação lenta e de caráter eletrônico de pás da hélice de um helicóptero modificado eletronicamente. Há um efeito doppler que dá a sensação de deslocamento desse som. Em seguida, um fade na imagem revela uma selva. Um helicóptero cruza o quadro da esquerda para a direita. O mesmo som da abertura acompanha o movimento do helicóptero fazendo com que o associemos à hélice. Começa então o som instrumental de abertura da canção The End pelo grupo The Doors. A poeira que levanta do chão é a deixa para mais duas entradas do som das pás, desta vez mais longas. Com a explosão de uma bomba de Napalm na floresta, ouve-se o começo do vocal da canção. Nenhum outro som além da canção será ouvido na trilha sonora enquanto Jim Morisson continuar cantando. Por mais estímulos visuais que a imagem traga (helicópteros, planos próximos das árvores em chamas, rosto de Willard), The End é suficiente para a ampliação de um estado letárgico no espectador iniciado pelas lentas 
pás das hélices girando. Murch, desta forma, concretiza a intenção de Coppola em Apocalipse: um filme psicodélico que tem a guerra do Vietnã como pano de fundo.

No fim da primeira parte do vocal, há uma passagem de bateria que serve como introdução de uma sessão instrumental. Murch aproveita essa entrada para criar mais tensão à música trazendo o som das pás, desta vez mais rápidas. Nesse trecho, ele também cria a primeira associação entre esse novo som e a imagem das pás de um ventilador de teto. Na volta do canto de Morrison, o som das pás permanece e é sincronizado com os helicópteros na imagem. À medida que os planos da selva desaparecem das fusões, permanecendo apenas os planos do quarto de hotel de Willard, The End vai desaparecendo da trilha sonora em 'fade out" com reverberação, restando apenas o ruído mais rápido das pás em movimento, agora diretamente associado ao ventilador de teto do quarto. Com o fim da canção, inicia um terceiro ruído de helicóptero. Este ruído se difere dos anteriores por ser composto de som de jatos e de ter as pás das hélices mais graves. O plano subjetivo de Willard se aproximando da janela tem seu movimento reforçado (e estimulado) por esse terceiro som de helicóptero que se afasta. No final da subjetiva o som desaparece dando lugar ao ruído da cidade que pode ser vista pela janela, a cidade de Saigon. Ouve-se um apito de policial, carros, buzinas, motocicletas, um leve vozerio e uma banda tocando. Em voz over, Willard começa a refletir sobre como não consegue mais se relacionar com as pessoas, como a luta na selva é a única forma de vịda que consegue ter e o cansaço da espera em Saigon. A medida que a voz over desenvolve o monólogo, a trilha de ambientes deixa de apresentar sons urbanos de Saigon e se transforma nos sons de uma selva. Os intervalos do apito do guarda diminuem e o som se transforma em cigarras. Em seguida, ouve-se macacos e pássaros. Uma buzina de carro toca em meio a todos esses sons. Na imagem, Willard tenta pegar uma mosca em seu travesseiro, mas o som ouvido é de um inseto da selva. Depois disso, a trilha de ambientes será apenas composta de sons da selva. No fim do monólogo de Willard, um som eletrônico semelhante a uma mosca é introduzido em meio aos pássaros e animais selvagens. Ele funciona como ponte sonora 
para a saída da trilha de ambientes e volta da canção The End. A canção segue até o fim da seqüência, acabando em fade junto com o fade out da imagem e encerrando o prólogo do filme.

Nesse prólogo de Apocalipse, Murch propõe uma nova forma de uso da trilha de ruídos e de ambientes, mudando o conceito da trilha sonora cinematográfica. $O$ primeiro ruído que cria para as hélices permite leituras diferenciadas. Uma naturalista, ao fazer uma sincronia perfeita entre esse som e os veículos que atravessam a tẹla e outra que vai além da simples representação sonora. O som das pás tem o tempo, o ritmo e a cor da viagem lisérgica proposta pela imagem. Seu movimento é lento, seu timbre agudo e reverberado como se ecoasse dentro da cabeça de alguém que esteja com sua percepção alterada por psicotrópicos. A escolha de The Doors para a trilha musical reforça o psicodelismo. Essa escolha é tão precisa que Murch. opta em toda a primeira estrofe da canção pelo seu uso apenas para compor a trilha sonora. Nem mesmo a grande explosão de napalm é sonorizada por ruídos de bombas ou fogo. A entrada da voz de Morrison nesse momento completa o impacto das chamas que queimam a floresta enquanto alargam o tempo da imagem.

Quando Murch retoma o ruído das pás, seu ritmo e timbre são diferentes. A velocidade de rotação é maior e o tom mais grave, aproximando-se do som de hélices reais. E é essa a leitura que nos é indicada por Murch, ao sincronizar o novo ruído com os helicópteros presentes na imagem. A manutenção desse ruído na segunda estrofe cantada de The End cria uma confusão sonora que reflete o estado de Willard naquele momento. Murch, em seguida, passa a sincronizar o segundo ruído de pás às imagens do ventilador de teto existente no quarto e faz com que nossa leitura desse som mude. A partir desse momento, passamos a entender que o som das pás sempre pertenceu ao ventilador e tudo que vimos e ouvimos até então era uma exteriorização da associação de pensamentos de Willard enquanto observa e escuta o ventilador. Um terceiro som de helicóptero, este sim naturalista, acorda Willard de seu devaneio e o leva até a janela.

É importante notar na câmera subjetiva que descreve a aproximação do perşonagem à janela, uma característica do pensamento audiovisual de Murch. O ideal é instigar o espectador 
não só visualmente ou auditivamente. Se existe a possibilidade de fazer com que som e imagem possam se complementar para aumentar o estímulo sensorial, esse será o caminho a seguir. O movimento descrito pela câmera subjetiva tem o mesmo percurso descrito pela saída do helicóptero que sobrevoa o hotel onde está Willard, levando ao espectador a sensação do deslocamento do personagem.

$\mathrm{Na}$ cena seguinte, Murch transforma ainda mais o uso da trilha de ambientes do que já havia feito em $O$ Poderoso Chefão. $\mathrm{O}$ uso expressionista do som ambiente desenhado na seqüência do restaurante daquele filme foi refinado e realizado de maneira mais complexa. O que ouvimos durante o monólogo de Willard não é a cidade que cerca seú apartamento e sim o que se passa em sua mente, sua emoções. À medida que aprendemos o horror pelo qual ele passa por estar em Saigon e sua vontade de retornar à batalha, os sons urbanos se mesclam com o ambiente da selva até que esses últimos passam a ser os únicos sons na trilha de ambientes. Dessa forma; Murch nos faz passar pelos mesmos sentimentos que a personagem. Porém, há um perigo muito grande nessa forma de utilizar a trilha de ambientes: como não há nenhuma referência visual ao que está sendo ouvido, pode acontecer um descolamento entre imagem e som causando um afastamento do espectador do filme. A solução que Murch dá a isso é um grande reforço aos ruídos de sala. Cada movimento de Willard; ao tentar capturar a mosca, ao pegar a foto da esposa, ao queimar a foto, é fortemente reforçado. Assim, ao mesmo tempo em que somos lançados na cabeça de Willard, os ruídos nos mantém ligados à imagem.

O som de uma mosca que depois se mostra um ruído eletrônico que depois se mostra um instrumento da trilha musical também cumpre várias funções. Primeiro, ele é integrado à selva da trilha de ambientes como mais um animal. Em seguida, reforça a sensação que Willard apresenta no texto como "paredes o espremerem pouco a pouco" ("each time I look around the walls move in a little tighter"').

Depois, ao revelar seu caráter musical, serve como ponte sonora para a volta de The End. Nessa retomada da música, Murch cria pequenas sincronias entre o que é visto e o que é ouvido, criando 
outra vez estímulos audiovisuais integrados. Um gonzo sincronizado ao movimento rotatório do braço, a voz de Morrison que chama a atenção de Willard e faz com que ele abra os olhos, o movimento ascendente da guitarra reforçado pelo movimento do braço que se afasta da câmera, o grito de Willard sincronizado à voz de Morrison, a aleatoriedade dos cortes entre os planos em que ele se embebeda são semelhantes à aleatoriedade da música até o final, onde Willard cai no chão no mesmo momento em que a canção tem a batida de seu último tempo forte. A diluição da música acompanha a diluição da imagem de Willard em um fade out para preto.

Ainda merece ser observado nessa seqüência o timbre da voz over de Willard. Ela não segue o padrão de gravação normalmente associado a esse tipo de locução, onde as freqüências médias da voz são valorizadas, criando uma sensação de maior presença do personagem. A opção de Murch foi posicionar Martin Sheen bem próximo ao microfone e fazer com que ele falasse quase sussurrado. $O$ resultado desse tipo de gravação foi um timbre mais grave que resulta em uma voz mais etérea, menos pertencente ao espaço físico. É esse padrão de voz que será usado em todas as entradas da voz over de Willard:

A sequiência 02 (Chegada dos soldados) é construída de forma oposta à sequiência anterior. Se a extrema manipulação das trilhas de ruídos, ambiente e música caracteriza o prólogo do filme, esta sequiência é baseada nos ruídos e vozes captados pelo som direto. O ambiente, mixado com pouca intensidade, é urbano. A reverberação das vozes e ruídos no corredor, dentro do quarto e do banheiro cria a sensação espacial. Nesta seqüência, uma outra característica de Murch é exposta: o uso do som em off para acrescentar mais informações sobre os personagens. Neste caso, Murch se utiliza da espera dos militares enquanto Willard abre a porta para acentuar a prisão que ele transformou seu próprio quarto. Mesmo que apenas vejamos uma porta nua no corredor, ouvimos muitas trancas e fechaduras sendo abertas em off, indicando a cela em que Willard quis se isolar durante sua estada em Saigon.

O corte para a seqüência 03 (Externa acampamento/ Almoço) é bastante semelhante ao corte usado em $O$ Poderoso 
Chefão entre as seqüências 79 e 80 (grito de Connie para choro de bebê). O grito de Willard ao ser colocado debaixo do banho frio é emendado por corte seco ao ruído do helicóptero que chega na base militar.

O ruído deste helicóptero se difere dos até então apresentados no filme por ter o som dos jatos e do motor mais intensos do que o som das hélices. Logo após o corte esse som é jogado para segundo plano, dando espaço a voz over de Willard. Durante a cena externa da base militar, Murch cria o ambiente com as vozes e os ruídos de soldados se exercitando. No corte para a interna do bangalô de Corman, esse ambiente é substituído por uma leve música erudita, criando conflito com o espaço da ação. Alguns helicópteros passam em terceiro plano de som, mantendo a continuidade externa/interna. No começo do almoço, a música erudita é substituída pelos ruídos de sala dos personagens comendo à mesa. Esses ruídos são mixados em primeiro plano de som, acompanhando os primeiros planos de imagem e enfatizando o absurdo da suntuosa refeição em meio à guerra que os cerca. Esse conflito é ainda mais acentuado pela manutenção dos brilhantes ruídos de sala sobre a voz pré-gravada de Kurtz, descrevendo os horrores do campo de batalha. A passagem de um helicóptero no fundo do monólogo de Corman sobre o lado negro das pessoas gera a tensão no ambiente, assim como o trem em $O$ Poderoso Chefão. Na saída do helicóptero, o silêncio gera um falso relaxamento na conversa. $O$ efeito de tensão dado por helicóptero é repetido quando Willard descobre a sua missão: matar Kurtz. Esse helicóptero tem um som ainda mais agudo do que os outros já apresentados, acentuando ainda mais a sensação nervosa da cena. A entrada da trilha musical fará a ponte sonora para a seqüência seguinte.

A sequiência 04 (Aérea Vietnã) inicia com um plano aéreo de campos do Vietnã. O som do helicóptero usado na cena anterior é sincronizado com o helicóptero da imagem, mudando sua função para um elemento diegético.

$\mathrm{Na}$ seqüência 05 (Barco no rio/Apresentação da tripulação/Satisfaction) é feita a apresentação dos companheiros de viagem de Willard. No primeiro plano do interior do barco, Murch 
traz os ruídos de sala dos personagens andando e um leve vozerio de fundo. Com o fim da voz over, são introduzidos o motor do barco que timbra com as notas finais da música, a água sendo deslocada pelo movimento do barco e o rádio em off tocando "Good Morning Vietnan". Murch utiliza o corte para o plano externo do barco descendo pelo rio para aumentar o volume do programa de rádio. Após um breve comentário do locutor, começamos a ouvir Satisfaction, dos Rolling Stones. Essa canção começa como som diegético, vindo do rádio de $\mathrm{Mr}$. Clean, e aos poucos aumenta em intensidade e em timbre, ganhando mais freqüências graves e agudas e passando a ocupar o primeiro plano de som. Desta forma, a música deixa de ser diegética e ocupa o espaço de som normalmente destinado à trilha musical não diegética. Mais uma vez, para evitar ùm estranhamento no espectador pelo uso não naturalista da trilha sonora, Murch mantém o vínculo com a imagem pela sonorização dos ruídos provocados pelos personagens e das suas vozes. Um cross fade entre "Satisfaction" e a trilha musical original do filme faz a passagem para a próxima sequiência.

O padrã̃o sonoro criado para a seqüência 06 (Leitura dossiê Kurtz), será o mesmo de todas as sequiências em que Willard estuda os documentos sobre Kurtz. A voz over de Willard ocupa o primeiro plano de som, a trilha musical original indica seus sentimentos num segundo plano, enquanto os ruídos de sala da manipulação dos papéis e das fotos, no terceiro plano da trilha sonora, fazem a ligação com a imagem.

A seqüência 07 (Encontro com Cavalaria Aérea/Encontro com Kilgore) inicia com uma explosão que tira Willard de seus pensamentos, trazendo-o de volta à realidade da viagem. A saída da música reforça esta idéia. No fim da voz over de Willard apresentando a divisão de cavalaria aérea, Murch acrescenta ruídos de helicópteros, vozes, tiros, bombas e ruídos de sala para criar o ambiente de confusão que a presença da divisão causou em seu ataque não programado. Assim como no prólogo, vários movimentos apresentados na imagem são reforçados pelo som de deslocamento de helicópteros.

A concepção de mixagem que Murch utiliza nessa seqüência é a mesma que usará em todas as sequiências de batalha em 
Apocalipse: Apenas três grupos temáticos de elementos sonoros (tais como helicópteros, tiros, explosões, vozes, passos) são ouvidos simultaneamente. Enquanto um dos grupos ocupa o primeiro plano da trilha sonora (normalmente um detalhe do plano de imagem), o segundo grupo é mixado com menos intensidade para dar a continuidade sonora e o terceiro grupo, com volume menos intenso ainda, entra ou sai em fade. Esta é a forma que Murch encontrou para que todos esses sons possam ser ouvidos claramente. É a velocidade que os grupos temáticos são trocados na trilha. sonora que gera o ritmo interno da mesma: Quanto maior a mudança desses grupos dentro da trilha sonora, através de seus diferentes níveis de intensidade e dos próprios grupos formadores dessa trilha, maior será o ritmo criado na seqüência.

A sequiência 11 (Ataque à aldeia) é um dos melhores exemplos da relação entre música, ruído e vozes proposta por Walter Murch, especialmente no que concerne às relações entre texturas e movimentos de imagem e texturas e movimentos de som.

A primeira cena da aldeia vietnamita é apresentada por leves pássaros e um cachorro latindo que criam um ambiente leve. As vozes das crianças que saem da sala de aula cantando completam a inocência do espaço. As vozes se dispersam e são substituídas pelas da professora e do soldado com seus respectivos ruídos de sala. Um sino entra em primeiro plano anunciando o futuro ataque. Enquanto as crianças saem de quadro, ouve-se em terceiro plano de som o ToYo-Ho, trecho da Cavalgada das Valquírias que já havia sido apresentado em sequiência anterior.

A mesma intensidade de música é mantida no corte para os helicópteros se aproximando da praia. No plano seguinte, a câmera ocupa um lugar entre os helicópteros. Á́ria passa, então; para primeiro plano de som e hélices agudas de helicópteros são ouvidas em segundo plano. O fim de uma frase musical leva ao plano dos vietnamitas correndo pela ponte. A ária cai em intensidade e ganha reverberação. As hélices passam a ser ouvidas com um timbre grave. A característica sonora da música não é modificada por um longo tempo, dando continuidade à cena. Apenas a mudança do timbre das hélices indica a proximidade dos atacantes. Para alterar a sonoridade da 
música, Murch se aproveita da linha melódica do To-Yo-Ho e cria um ruído de hélices que tem o mesmo desenho da melodia. Assim, a ária não é escondida pelo ruído sem perder continuidade. No plano séguinte, a aldeia sendo vista pelo piloto de helicóptero, fica quase imperceptível que a música não sofreu transformação.

O fim do canto do soprano traz a volta do tema da Cavalgada com uma entrada grandiosa da orquestra. O tempo forte dessa entrada é também o tempo forte para o começo do ataque. (Fica clara a intenção de criar toda essa parte da sequiência pela música, pelo canto do soprano, pelo não uso da voz de Kilgore falando no headset em primeiro plano) A primeira forma que a trilha sonora tem durante o ataque é a trilha musical sendo mantida em primeiro plano, tiros e vozes dos pilotos variando em segundo plano conforme a imagem mostra a aldeia ou o interior dos helicópteros e, em terceiro plano, o som das hélices. Na explosão da casa simultânea à chegada dos helicópteros sobre a aldeia, Murch faz um respiro na música, colocando-a em segundo plano e traz para frente o som de explosões e tiros. As vozes dos, soldados ficam variando entre segundo e terceiro planos de som.

O fim da primeira entrada do soprano (uma nota longa) é associado a um longo plano rasante sobre as copas das árvores encerrando a primeira parte da sequiência - marcada pela grandiosidade e por planos onde os helicópteros e as armas e explosões são os elementos principais. A segunda etapa é intermediária na troca do personagem principal: se na primeira etapa são as máquinas, na terceira, são os soldados norte-americanos. Nesse fragmento intermediário, planos de batalha são montados com planos de falas dos soldados. A trilha sonora segue uma constância com a música, ocupando o segundo plano com dois desenhos diferentes: orquestra sem soprano e soprano sem orquestra, ambas com reverberação para diminuir sua presença. $O$ primeiro plano de som é ocupado por vozes ou tiros seguindo a imagem. Já no terceiro plano, continuam as hélices que se alternam entre as de timbres agudos e graves para os planos mais próximos e mais afastados dos helicópteros. Outro plano rasante, desta vez sobre uma nuvem de fumaça, faz uma cortina para o início da 
terceira parte da seqüência. A trilha sonora aproveita a mesma cortina para encerrar To-Yo-Ho em fade out.

O terceiro bloco é composto por duas cenas: a perseguição e destruição do carro sobre a ponte e o helicóptero de Kilgore sendo atingido. Vozes humanas estão sempre em primeiro plano de som, sejam elas ouvidas ou não pelos fones de ouvido. Em segundo plano, entram bombas e tiros, enquanto o terceiro plano se mantém constante. A volta da Cavalgada das Valquírias marca o início da quarta parte da sequiência: o desembarcar da companhia e ataque à aldeia pelo solo. Tanto a imagem como o som retomam a estrutura da primeira parte. A exceção se dá em uma curta cena onde um soldado se recusa a descer do helicóptero. Nesșe momento, há uma interrupção da música para que a voz do soldado seja ouvida em primeiro plano. No fim da cena, To-Yo-Ho volta a dominar a trilha sonora até desaparecer três planos depois por baixo do som de vasos explodindo. A partir daí, o filme retoma seu foco principal nos soldados até o fim da sequiência. Na trilha sonora, as vozes sincrônicas com a imagem ocupam o primeiro plano de som. No terceiro plano de som, alternamse explosões, tiros e helicópteros, enquanto o segundo plano de som apresenta um vozerio dos soldados americanos, reforçando ainda mais a opção pelo humano a partir desse ponto.

A seqüência 14 (Chef e Willard colhem mangas) apresenta outra inovação de Murch na criação da trilha sonora cinematográfica. Conservando a idéia de usar a trilha de ambientes para expressar as emoções dos personagens, Murch faz uso de uma característica da audição humana: a audição seletiva. A audição seletiva permite que selecionemos um som entre vários outros para ser ouvido. Ela é o mecanismo utilizado cada vez que procuramos alguma informação sonora. Nessa sequiência, Chef decide catar mangas para preparar um chutney. Ela se inicia com as vozes no barco subindo em fade até alcançar o primeiro plano e muitos pássaros ocupando o resto da trilha sonora. Esses sons se misturam a outros animais da floresta quando Willard e Chef se embrenham no mato. Quando Chef pára para urinar, Willard ouve um ruído semelhante a alguém pisando em folhas secas. Diante do perigo da existência de vietnamitas no lugar, Willard se concentra para tentar achar a origem do som. A floresta 
se cala e a trilha sonora passa a acompanhar as escolhas sonoras de Willard. Na revelação que o ruído havia sido feito por um tigre, a floresta volta à intensidade original. A sobreposição de vozes gritadas, os sons de tiros e do motor do barco reforçam a confusão do fim da seqüência. Sob o primeiro plano do rosto de Willard, os gritos do Chef começam a sair em "fade" e são substituídos pela trilha musical, marcando o início da seqüência seguinte.

A sequiência 20 (Vistoria no barco vietnamita - Fade out) também exemplifica como Murch altera os sons ambientes dentro de uma mesma sequiência para marcar as nuances dramáticas. A cena inicia com alguns juncos navegando pelo rio. A trilha musical cai para terceiro plano de som até desaparecer no momento que Chief resolve investigar um dos juncos. A partir desse ponto, não há qualquer outro som na trilha que não seja vindo de um dos dois barcos. Dessa forma, toda a nossa atenção é concentrada nesses personagens. A quantidade e densidade dos ruídos refletem os três diferentes momentos da sequiência. No início, sons esparsos de animais criam um ambiente de tranquiilidade. A partir do momento em que as vozes dos soldados começam a se sobrepor, quando Chef vai investigar dento do barco, os ruídos também são sobrepostos para aumentar.o ritmo interno da sequiência. Os tiros de metralhadora encobrem todos os outros ruídos, causando impacto durante seu uso. A revelação da vietnamita estar viva é feita sob tensão marcada na trilha sonora pelo uso contínuo de estridentes cacarejos. Depois da morte da camponesa, Murch opta por esvaziar a sonoridade da seqüência encerrando o som das galinhas e substituindo por sons pontuais de um pássaro em vôo. O fade para preto da imagem é acompanhado por um fade out no som.

Na seqüência 23 (Brumas/Assassinato Chief), Murch usa o mesmo recurso narrativo com uma sonoridade distinta. $\mathrm{O}$ barco onde estão Willard e seus colegas navega pelo rio envolto em brumas. Gritos vindos da margem entram em segundo plano de som, criando um ambiente fantasmagórico que é reforçado pelos gritos de Lance dentro do barco. Com o avanço do barco, músicas e apitos se misturam às vozes, criando uma sonoridade ainda mais ameaçadora. Ao entrar a voz de Willard, sai a música original. Durante a fala 
over, os gritos e a música diegética vão sendo reduzidos até sobrar apenas o som de grilos ao seu final. Esse recurso cria um ambiente quase silencioso que abre espaço para o som de lanças se deslocando no ar, acompanhando o novo ataque na imagem.

Mais uma vez, Murch cria um susto no espectador. Se em poucas cenas atrás, o recurso usado foi o corte bruto, desta vez há uma nova opção: o esvaziamento da trilha sonora sob a voz de Willard, um breve momento de descanso da audição e o impacto da entrada do novo som. Com a saída brusca do barco, o som do seu motor toma o primeiro plano, deixando o som das lanças em segundo plano junto com os tiros e as reações dos personagens no último plano de som. Durante a conversa de Chief com Willard, as lanças são reduzidas em intensidade. Por baixo delas, voltam os gritos das pessoas na beira do rio enquanto os tiros são ouvidos apenas nos intervalos do diálogo. No fim da conversa, os tiros voltam a ser constantes no primeiro plano de som, o motor do barco volta ser ouvido fortemente e pássaros emitindo sons agudos são somados à trilha. Esse caos sonoro segue até que o deslocamento de uma lança entra em primeiro plano de som, e a imagem revela Chief sendo alvejado. Nesse momento, o som do motor do barco é drasticamente reduzido, e todos os tiros e lanças se calam. Durante a queda de Chief, os pássaros também são retirados em fade, restando na trilha sonora apenas o som grave do motor do barco sendo usado como um elemento de tensão. Quando Chief e Willard tentam matar um ao outro, esse ruído sobe lentamente em intensidade e desaparece completamente com a morte de Chief. Murch faz um uso quase musical do ruído, fazendo com que as alterações de intensidade reflitam a raiva e a morte do personagem.

Ao contrário da maioria das seqüências de Apocalipse, onde a música composta é associada a sequiências de passagem ou às leituras de Willard sobre Kurtz, ela acompanha grande parte da seqüência 21 (Fade in - Barco no rio/Ponte Do Lung), possivelmente a sequiência mais alegórica do filme. Esta seqüência é isolada do resto de Apocalipse por duas pontas pretas. Sua estrutura sonora é apoiada na música extra-diegética, com exceção da cena da trincheira onde também há música, mas, desta vez, diegética. Os 
demais elementos sonoros - morteiros, explosões, tiros de metralhadoras - também são utilizados para a formação de um clima onírico, assim como os gritos em off dos vietnamitas.

A música da seqüência anterior atravessa a ponta preta e termina na primeira imagem da seqüência 22 - um plano traseiro do barco pelo rio. Uma nova composição original para o filme inicia logo em seguida, criando um clima de tensão sob as imagens dos soldados recebendo cartas. Uma segunda cena acontece quando Willard recebe suas novas ordens. A estrutura "voz over" - música é repetida. No fim da leitura da carta, a trilha musical retoma $o$ tema inicial da seqüência. Em seguida, Lance começa a soltar fumaça, gerando confusão no barco. A trilha sonora acentua a confusão, alterando constantemente a intensidade entre os elementos formadores da trilha sonora: o ruído do spray de fumaça, os comentários de Chief, a voz da mãe de Mr. Clean no gravador e os gritos de Lance. Apenas a música permanece constante em segundo plano de som.

Ao primeiro disparo de morteiro na imagem, a trilha sonora é bruscamente substituída pelos sons de batalha (morteiros e tiros) em primeiro plano de som e reações dos ocupantes do barco em segundo plano. Por esse corte de som, Murch repete no espectador a surpresa dos soldados. No fim do ataque, resta na trilha sonora apenas o motor do barco. A trilha sonora original é retomada na descoberta da morte de Mr. Clean. Somam-se a ela na trilha sonora as reações dos companheiros e a voz da mãe vinda do gravador, que comenta a festa que está sendo preparada para a volta de Mr. Clean. Essa voz constante em segundo plano de som aumenta a tragédia da morte. Pouco depois do fim da gravação, a trilha musical passa a ser o único elemento formador da trilha sonora.

A seqüência 29 (Willard com Kurtz) apresenta o primeiro encontro de Willard com Kurtz. O ambiente da casa de Kurtz permanece o mesmo durante toda a sequiência: os grilos que iniciaram na seqüência anterior e sons de água corrente ou pingando. É através dos sons de água que Murch cria profundidade no espaço interno da casa. A reverberação nas vozes de Willard e Kurtz completam a sensação de um lugar grande e fechado. Quando Kurtz 
conta a Willard que sabe qual a sua missão, a trilha musical volta ao segundo plano de som e continua até o fim da seqüência, reforçando o diálogo sobre a morte de Kurtz.

O silêncio do ambiente de Kurtz é quebrado no início da seqüência 30 (Prisão de Willard). Enquanto o Fotógrafo caminha em direção à cela de Willard, podemos ouvir moscas rondando os cadáveres pendurados, cigarras, pássaros e outros animais da selva, porcos, voz de criança falando, vozes de homens cantando, eventuais gritos masculinos e ruídos de folhas balançando ao vento. Esta trilha de ambiente cria o movimentado espaço da cidade comandada por Kurtz. O diálogo entre Willard e o Fotógrafo permanece sempre em primeiro plano de som. Murch, mais uma vez, faz uso dos sons ambiente de forma não-naturalista para intensificar o discurso do Fotógrafo em defesa de Kurtz. A crescente exaltação do Fotógrafo é acompanhada por uma trilha de ambiente com sons de animais cada vez mais intensos até que, no ápice de sua fala, todos os animais que compõem o ambiente estão gritando. Para intensificar ainda mais o final da cena, Murch soma aos gritos o som em off de batidas ritmadas às vozes cantando. No fim da seqüência, o Fotógrafo se acalma assim como os sons ambientes.

A seqüência 35 (Willard no barco/Ritual/Morte Kurtz) se inicia no barco de Willard e segue com uma seqüência paralela dos seguidores de Kurt matando um boi enquanto ele é assassinado. Mais uma vez, a trilha sonora não segue por toda a seqüência o que é mostrado pela imagem e sim, acentua os pontos dramáticos das cenas. Enquanto Willard permanece no barco, ouvimos uma voz vinda do rádio pedindo confirmação de recepção da transmissão. Com o início da voz over de Willard, o rádio desaparece. Durante todo o texto, a canção The End é retomada por um lentíssimo fade de entrada que no fim do monólogo assume o primeiro plano de som. No corte de imagem para a cerimônia, The End não sofre alteração de intensidade. Os sons do ritual que já estiveram um primeiro plano em seqüências anteriores são retomados em terceiro plano de som. Apenas eventuais trovões completam a trilha sonora durante a aproximação de Willard da casa de Kurtz. Ao descobrir Kurtz lendo, The End cai para segundo plano de som, enquanto a 
voz de Kurtz ocupa o espaço sonoro principal. No fim do texto, The End passa a ser o único elemento da trilha sonora. Os ataques fortes da canção servem para acentuar as facadas de Willard em Kurtz e dos seus servidores no boi. $O$ fim da canção é marcado por um trovão que anuncia as últimas palavras de Kurtz: the horror. Com sua morte, há uma respiração de silêncio na trilha sonora. Em seguida, a música original passa a ser o único elemento da trilha sonora. Vemos Willard caminhar entre habitantes da cidade, acompanhado por ruídos de sala que são retomados em segundo plano de som, recriando o vínculo naturalista com a imagem. $\mathrm{O}$ fim da música acontece com o plano do barco partindo.

\section{Considerações finais}

A forma de Walter Murch pensar a trilha cinematográfica influenciou e ainda influencia o trabalho dos criadores de trilhas sonoras cinematográficas. Ela pode ser notada na interação entre músicas e ruídos criada por Richard Beggs em O Selvagem da Motocicleta (1983) ou no uso expressivo dos sons ambientes que Alan Splet faz em Veludo Azul (1986) e Randy. Thon, em Coração Selvagem (1990), ou mesmo na trilha de ruídos realizada por Ben Burtt em Guerra nas Estrelas. Todos eles projetistas de som/sound designers.

A mais importante obra de Murch está em reacender a discussão do uso da trilha sonora em um meio audiovisual. Uma discussão que continua até hoje. Cada vez mais, a trilha sonora e todos os seus elementos formadores são fundamentais no processo de criação e realização de um filme. Obras atuais como Os Incríveis, O Senhor dos Anéis, ou um pouco mais antigos como Um Céu de Estrelas são estruturadas tanto na imagem e na voz, quanto na música e nos ruídos. Qualquer tipo de hierarquização entre esses elementos desfiguraria tanto esses trabalhos que seria praticamente impossível sua compreensão.

Até hoje, Walter Murch continua pensando a trilha sonora e abrindo novas discussões que expandam ainda mais os limites criativos das obras audiovisuais, como nesta reflexão sobre o som e o futuro do cinema: 
A película vai acabar desaparecendo e você irá ao cinema e vai ficar olhando pra algum tipo de tela de cristal líquido sem linhas. Será que existe alguma diferença entre isso e a película? $O$ que é estranho na película é que quando você vai ao cinema e sai duas horas depois, você ficou uma dessas horas em total escuridão. Metade do tempo você passou olhando para uma tela preta, que é resultado do mecanismo do obturador do projetor. Será que essa tela preta faz com que o som funcione de maneira diferente? Eu diria que ele libera alguma parte do seu cérebro para perceber de forma diferente do que quando você está olhando para uma emanação constante de luz, que é a televisão. Se existir a tela de cristal líquido, ela piscaria de forma artificialmente induzida ou teria sempre luz?

As pessoas vão continuar indo ao cinema? Se não forem, como será sua casa? Teriam uma televisão de cristal líquido de três por quatro metros que fique pregada na parede fazendo um dos cantos da sala ter somente essa tela? Você aperta o canal 432, um dos muros da sua sala desaparece e o que você vê é uma transmissão ao vivo de um vulcão na América do Sul ou a Terra vista da Lua. Qual é o som pra isso? Se você puder realmente sintonizar a Terra vista da Lua, ao vivo, toda nossa relação com a Terra mudaria. Quando existir esse canal lunar 432 e você vir a Terra bem na sua frente, ao invés de uma quarta parede, qual é o som pra isso?" (LoBrutto, 1994, p.99).

\section{Bibliografia}

ALTMAN, R. 1992. Sound Space. In: ALTMAN, R. (ed.) Sound theory, sound practice. New York: Routledge.

CHION. M. 1994. Audio-vision: sound on screen. New York: Columbia University Press. 
EISENSTEIN, S. 2002. A forma do Filme. Rio de Janeiro, Zahar.

GIRALDO-SALINAS, F. J. 1989. Da "dupla dinâmica" somimagem: uma aproximação teórica ao som na televisão. São Paulo: 196 p. Dissertação de Mestrado - Escola de Comunicações e Artes, Universidade de São Paulo.

LOBRUTTO, V. 1994. Sound-on-film; interviews with creators of film sound. New York: Praeger.

ZETTL, H. 1973. Sight, Sound, Motion: Applied Media Aesthetics. Belmont: Wandswirth.

\section{Filmografia}

APOCALIPSE (Apocalypse Now). 1979. Francis Ford Coppola. San Francisco, CA: Zoetrope Studios: United Artists. 8 rolos (153 min.): son., color.; $35 \mathrm{~mm}$.

CAMINHOS MAL TRAÇADOS (The Rain People). 1969. Francis Ford Coppola. San Francisco, CA: American Zoetrope: Warner Brothers/Seven Arts. 6 rolos (102 min.): son., color.; 35mm.

A CONVERSAÇÃO. 1974. Francis Ford Coppola. San Francisco, CA: The Directors Company: Paramount Pictures. 6 rolos (113 min.): son., color.; $35 \mathrm{~mm}$.

LOUCURAS DE VERÃO (American Graffiti). 1973. George Lucas. San Francisco, CA: The Coppola Company: MCA/Universal Pictures. 6 rolos (112 min.): son., color.; $35 \mathrm{~mm}$.

O PODEROSO CHEFÃO. 1972. Francis Ford Coppola. Los Angeles, CA: Paramount Pictures: Paramount Pictures. 9 rolos (175 min.): son., color.; $35 \mathrm{~mm}$.

O PODEROSO CHEFÃO II (The Godfather - Part II). 1974. Francis Ford Coppola. San Francisco, CA: The Coppola Company: Paramount Pictures. 10 rolos (200 min.): son., color.; $35 \mathrm{~mm}$.

THX 1138. 1970. George Lucas. San Francisco, CA: American Zoetrope: Warner Bros. Pictures. 5 rolos (88 min.): son., color.; $35 \mathrm{~mm}$. 